\title{
CLINICAL CHARACTERISTICS OF COVID-19 PATIENTS AT THE WISMA ATLET PADEMANGAN, JAKARTA
}

\author{
Denni Marvianto, Bara Kharisma, Amelia Fitra Khasanah, \\ Theodora Injang Winedar
}

Wisma Atlet Pademangan, Jakarta Utara, Jakarta

\begin{abstract}
Background: COVID-19 pandemic has affected more than 200 countries. Severe Acute Respiratory Syndrome Coronavirus (SARS-CoV-2) virus infection can be asymptomatic, mild, or severe. Because of these highly variable manifestations, knowledge of the clinical characteristics of COVID-19 patients can assist in determining appropriate strategies for dealing with COVID-19 in the future. The purpose of this study was to determine the clinical characteristics of COVID-19 patients at Wisma Atlet Pademangan.

Subjects and Method: This was a descriptive study. The variables in this study were clinical characteristics in COVID-19 patients. The population studied were COVID-19 patients who were isolated at Tower 8 Wisma Atlet Pademangan, Jakarta, from November 10, 2020, to December 10, 2020. A total sample of 403 patients was selected for this study. Primary data were collected by using google form. Data were analyzed descriptively.

Results: The results showed 202 COVID-19 patients were asymptomatic (50.1\%), 201 with mild symptoms (49.9\%). In patients with mild symptoms, myalgia (38.81\%) was found, followed by fatigue (37.81\%), fever (37.31\%), hyposmia (36.32\%), headache (36.32\%), cough (35.82\%), and productive sputum (34.83\%).

Conclusion: Half of the patients were asymptomatic or mild symptoms. In patients with mild symptoms, the most common complaint is myalgia. Other symptoms often found in a row are fatigue, fever, headache, hyposmia, and cough.
\end{abstract}

Keywords: COVID-19, clinical characteristics

\section{Correspondence:}

Denni Marvianto. Wisma Atlet Pademangan. Pademangan Timur, Pademangan, Jakarta Utara, Jakarta 14410, Indonesia. Email: dennimarvianto@gmail.com. Mobile: o8998109326. 